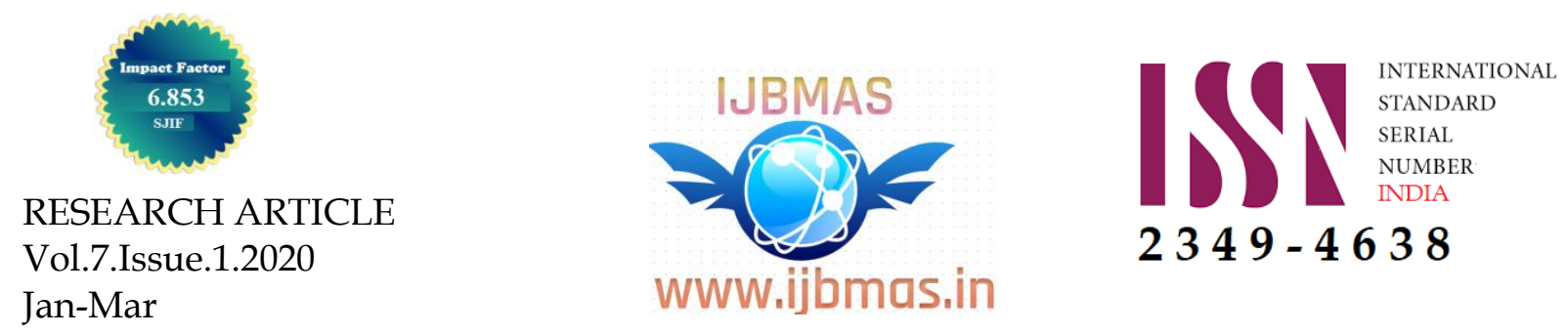

INTERNATIONAL JOURNAL OF BUSINESS, MANAGEMENT AND ALLIED SCIENCES (IJBMAS)

A Peer Reviewed and refereed Journal

\title{
ONLINE MARKETING SIGNIFICANCE FOR RURAL CONSUMER WITH CONTEXT OF INDIA
}

\author{
Dr. SAGAR F. JADHAV*1, Dr. AARTI DESHPANDE ${ }^{2}$ \\ ${ }^{1}$ Assistant Professor, G.H Raisoni College of Commerce, Science \& Technology Nagpur \\ *E-mail id: - jadhav.sagar4@yahoo.com \\ ${ }^{2}$ Officiating Principal, G.H Raisoni College of Commerce, Science \& Technology, Nagpur \\ DOI: $\underline{10.33329 / \text { ijbmas.7.1.23 }}$
}

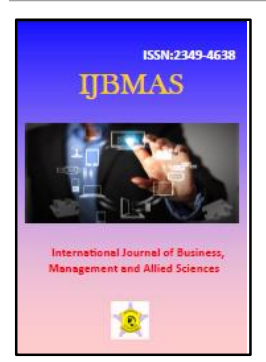

\begin{abstract}
The advancement of online marketing or online marketing has become crucial for any business, firm, enterprise or organization across the globe. The consumer behavior study has been becoming more catchy and centric and crucial for any business in any industry. The significant objective of the paper is to obtain quantitative describing the actuality of digital marketing in the case of India to explain the development of digital marketing and its consequences on rural consumer behavior in Nagpur city. The research paper built on the relevant study literature and at the same time examines the rural consumer behavior in the Nagpur rural area. Furthermore, this paper supports the research questions that include recent trends and different issues in digital shopping, and impact factors for rural consumer behavior.

Also, the result of the research shows that Internet marketing has a significant impact on consumer buying decisions and Internet marketing has a wide internet technology adoption among consumers in Nagpur district. Apart from this Consumers` trust, privacy concerns, security concerns are the major factors for using the internet for shopping, the trust on websites influence the purchasing decision of the rural consumer.
\end{abstract}

Keywords: Digital marketing, rural consumer, consumer behavior, privacy and security, consumer trust.

\section{INTRODUCTION}

In today's highly competitive market scenario, the marketer cannot sell the product without marketing efforts and what he offers to sell or produces, but he can successfully sell only proper marketing what is desired by the consumer. 
But what the consumer desire is not easy to perceive. This brings a big problem before the marketer. This problem can be solved only by getting the necessary information regarding the consumers and market conditions. If the information reveals that consumers are not satisfied with the marketer's products or services, he decides to adapt it accordingly. This helps the marketers to raise the level of performance of the organization and modify the current marketing strategies.

Since the survival and growth of a company depends upon the satisfaction of the needs and wants of the consumers it serves, it is measurable for a marketer to monitor continuously the trend of the consumer market and its behavior before a sound marketing plan can be developed or modified to serve the consumers. Consumer behavior in management is a very crucial and important discipline. Various Scholars and academicians concentrated on it at a much later stage.

According to Philip Kotler and Gary Armstrong, "consumer behavior refers to the buying behavior of final consumers - individuals and households who buy goods and services for personal consumption. All of these final consumers combined make up the consumer market."

Different consumers have various needs and want them to belong to various age, income, and sex, education and occupational groups. These consumers also purchase a variety of goods and services. How the diverse consumers make their choice among the various products is an interesting issue a marketing facility opens different new golden avenues and opportunities to market out several kinds of goods \& services of various industries. Local businesses can be easily converted into global by just clicking and developing a shopping website into the web servers. Any business can pick up an appropriate online Marketing business model from the list of B2B, B2C, and C2C, etc.

E-Marketing also referred to as digital marketing, i-marketing, web-marketing, online marketing or internet marketing is the marketing of goods \& services or services over the Internet.

Internet Marketing is that aspect of marketing that essentially deals with planning, pricing, promotion, and distribution of products and services by using internet applications. It includes website design, search engine optimization, directory submissions, reciprocal linking strategies, online advertising, and email marketing.

"E-Marketing is described by the institute of direct marketing as the use of the internet and related digital information and communication technologies to achieve marketing objectives.

The Internet has become wider and brought media to a global level. E-Marketing is sometimes considered to be broad in scope because it not only refers to marketing on the Internet but also includes marketing done via email and wireless media and much more. Businesses can send emails/newsletters to their potential consumers to make them aware of their existing or new goods \& services.

\section{Significance of the study:}

The present study deals with digital marketing aspects of rural consumer behavior in 21 centuries. It is the most visible component of digital marketing. Digital marketing carries out the function of promotions and online advertising along with other necessary activities. Internet marketing is nothing but marketing via the Net. It is an interface between the online customer and the Marketing function of the business firms.

Online businesses or companies can sell their goods \& services 24 X 7 Hours and 365 Days a year without interruption using their online / eMarketing concepts. The business sells its variety of products through useful sites such as Amazon, Flipkart, Ebay, Snapdeal, etc. and bears the cost of technology.

Consumer behavior study insight into their consumption-related decisions; what they buy, when they buy, why they buy, how they buy and the promotional influences that persuade them to buy. The study of consumer and consumer buying behavior will enable them to become better and wiser online consumers. 
Scope of the Study:

In this paper, the study and survey would be conducted each and every one the way through a questionnaire to gather the statistics and facts from the targeted respondents of the rural consumer in Nagpur city. To the impact of internet marketing on consumer behavior to measure the effectiveness and applicability of E-Marketing approaches among rural consumers. Consumer behavior and internet marketing have a very wide scope to study how consumers decide to purchase a product online or on the internet. The internet has become an ongoing emerging source that tends to expand \& enhance more and more. The growth of this particular media attracts the eyes of advertisers as a more productive source to bring in online consumer's mind.

Most of the companies have put lots of effort and money to create an innovative and newer product for online selling every year. The present study is an endeavor to sketch the behavioral aspects of online consumer that which factors largely impact on consumer and different stages of the consumer decision making process in the online shoppers in Nagpur city.

\section{Objectives of the Research:}

The specific objectives of the paper are given below:

1. To study the acceptance of online marketing opportunities among rural consumers in Nagpur city.

2. To study the impact of online marketing on the purchase decision of rural consumers.

3. To study the awareness of online-marketing among the people in Rural Nagpur.

4. To study the significance of online marketing in the 21 century.

\section{LITERATURE REVIEW}

Bulkely and Carlton, (2000) the majority of Internet shopping behavior consists of one-time purchases, which is mainly according to consumer's different shopping motivations, such as convenience. Information technology has used in the form of the Internet to improve better quality of product information, which helps shopper's decision making (White, 1997).

A Demery (2010) report, the advantage of internet marketing is that some consumers find it convenient shopping, think that it saves their time, their money and observes that it is easier to find and buy particular products in online stores.

Gordan and Bhowan, (2005) found that security is the major factor that discouraged the target online consumer from purchasing on the internet. Security is an intensive factor for them. If there are security and trust consumers become loyal to internet shopping.

Ruchi Nayyar (2010) in the study of website factors on the internet shopping, buying behavior and the study found that online shoppers perceive different factors such as website design, fulfillment/reliability, privacy/security and consumer service impacting online purchase activity differently.

Michal Pilik, (2012) found that online consumers have some worries while purchasing on-line because of security, trust, and shipping of products and services.

Prasad and Aryasri (2009) have explored the determinants of shopping behavior such as convenience factors, customer service factors, trust factors, web security factors, and web shopping enjoyment and examine the effect of these factors towards online buying behavior of consumers.

Jush and Ling, (2012) examined that consumers can enjoy online shopping for 24 hours per day. Consumers can buy any goods and services anytime everywhere. Online shopping is more user- 
friendly compared to traditional shopping because consumers can just meet his desires, needs and want just with a click of mouse without leaving their home.

Swaminathan (1999) conducted the study entitled "browsers and buyers in Cyberspace? And found that consumer characteristics play a significant and important role in the consumer's decision-making process to shop online. He identified that convenient oriented consumer as the most potential online buyer since they value the convenience of shopping at home and it has become a motive for purchase.

\section{METHODOLOGY}

\section{Hypotheses of the study:-}

For the execution of the research, the following hypotheses are formulated and studied.

Appropriate statistical tests are used to test and validate the hypotheses.

The following hypotheses are:-

$\mathrm{H}_{\mathrm{a}}$ : Online marketing has no impact on the rural consumer buying decision

$\mathrm{H}_{0}$ : Online marketing has a significant impact on the rural consumer buying decision.

$\mathrm{H}_{\mathrm{a}}$ : Online marketing has a limited acceptance among rural consumers in Nagpur district.

$\mathrm{H}_{0}$ : $\quad$ Online marketing has wide acceptance among rural consumers in Nagpur district.

\section{The universe for the study:}

The universe or population represents the entire group of units which is the focus of the study Thus, the population or universe of the study consists of rural consumers from different areas of Nagpur city. The study has been carried out based on an adequate size of sampled consumers in rural areas throughout the Nagpur city, India. Consumers who have experience in buying the product, including students, Business professionals, and servicemen (Private and govt).

\section{Sampling Method:}

All samples are selected from the rural areas of the Nagpur district of India so; the research is carried out by random convenient sampling.

Random convenience sampling (also known as availability sampling) is a specific type of nonprobability sampling method that relies on data collection from population members who are conveniently available to participate in the study.

\section{Sample Size:}

The research study used a survey method for data collection. A sample of 300 respondents from Rural Nagpur was taken which 300 Nagpur rural consumers.

\section{Analysis of the study:}

After the collection of data, several closely related operations such as the establishment of categories, the application of these categories to raw data through coding \& tabulation are done and then statistical inferences are drawn. The collected data were in nominal, ordinal and interval form and hence simple percentile analysis of the data was done. The variables were analyzed based on their frequency of occurrence. The testing of hypotheses is done by analyzing the data using appropriate statistical tests such as one sample " $\mathrm{t}$ " test, with the help of Statistical Package for Social Science (SPSS Package) and the charts and graphs were prepared in MS excel 2010 version. 
Hypothesis-1. Testing

The mean value i.e. shows 2.96 and SD is 1.45 shows positive results towards digital marketing has a significant impact on the consumer buying decision. That means majority of respondents' rural feel that digital marketing has a significant impact on the rural consumer buying decision.

Table 1.1 descriptive statistics

\begin{tabular}{|l|l|l|}
\hline \multicolumn{2}{|l|}{ Rural consumers } \\
\hline N & Mean & SD \\
\hline 200 & 2.96 & 1.459 \\
\hline
\end{tabular}

This hypothesis regarding the role of internet marketing on the consumer buying decision is tested through a One-Sample t-test using statistical software SPSS.

\section{Rural Consumers:}

\begin{tabular}{|l|l|l|l|}
\hline $\mathrm{N}$ & Mean & Std. Deviation & Std. Error Mean \\
\hline 200 & 2.9600 & 1.45912 & .10318 \\
\hline
\end{tabular}

\begin{tabular}{|l|l|l|l|l|l|}
\hline \multicolumn{2}{|l|}{ Test Value $=5$} \\
\cline { 5 - 6 }
\end{tabular}

The test value is set at 5 as Likert scale is a five-level scale to record the responses. From the above One-Sample t-test hypothesis is significant, i.e. 0.000 of rural. So the NULL hypothesis is rejected and the alternate hypothesis 'Internet marketing has a significant impact on rural consumer buying decision' is accepted.

\section{Hypothesis- 2. Testing}

The mean value i.e. shows 1.9 and the SD is 1.24 shows positive result towards the acceptance of digital marketing is wide by the rural consumers in Nagpur.

Table 1.2 descriptive statistics

\begin{tabular}{|l|l|l|}
\hline \multicolumn{2}{|l|}{ Rural consumers } \\
\hline $\mathrm{N}$ & Mean & SD \\
\hline 200 & 1.9 & 1.24 \\
& & \\
\hline
\end{tabular}

These hypotheses regarding the acceptance of internet marketing amongst consumers in Nagpur District are tested through a One-Sample t-test using statistical software SPSS. 


\begin{tabular}{|l|l|l|l|}
\hline $\mathrm{N}$ & Mean & Std. Deviation & Std. Error Mean \\
\hline 200 & 2.3550 & 1.38512 & .09794 \\
\hline
\end{tabular}

\begin{tabular}{|c|c|c|c|c|c|}
\hline \multicolumn{6}{|c|}{ Test Value $=5$} \\
\hline \multirow[t]{2}{*}{$\mathrm{T}$} & \multirow[t]{2}{*}{ Df } & \multirow[t]{2}{*}{ Sig. (2-tailed) } & \multirow[t]{2}{*}{ Mean Difference } & $\begin{array}{l}95 \% \quad C \\
\text { Differe }\end{array}$ & Interval of the \\
\hline & & & & Lower & Upper \\
\hline-27.005 & 199 & .000 & -2.64500 & -2.8381 & -2.4519 \\
\hline
\end{tabular}

From the above One-Sample t-test hypothesis is significant i.e. 0.000 of both. So the NULL hypothesis is rejected and the alternate hypothesis 'Internet marketing has a wide acceptance among rural consumers in Nagpur district' is accepted.

\section{Limitations of the Study:}

The present study is based on primary statistics and facts taken from various respondents of Nagpur district, including only rural by filling a prescribed questionnaire. The purity of the result depends on the purity of the statistics and facts. Each conclusion and suggestion are given from the statistical analysis of the several coded data. The research is restricted to the Nagpur rural (Maharashtra state) city only.

\section{FINDINGS OF THE STUDY}

1. It was found that almost all the consumer had very strongly agreed to the fact that most rural consumers accept digital marketing has a significant impact on their purchase decision.

2. Online marketing provides the most satisfying experience and provides a unique experience for rural consumers. The reason is the online shopping sites offer attractive offers, free cash on delivery, gifts, coupons, discounts on products and time-saving.

3. Youngers/students do prefer more online shopping in rural Nagpur because they do shopping for fun and entertainment and are risk-takers and know the procedure of online shopping. The study found that young/ students prefer more online shopping than business professionals and farmers in rural.

4. Online shopping sites are offering different promotional schemes like discounts, gifts, free shipping, pay cash on delivery, combo packs, and value for money schemes to attract and retain the customers.

5. Rural consumers were hesitant while shopping online because of security issues of their payment mode and risk of the products. 


\section{SUGGESTIONS OF THE STUDY}

1. The study suggests that Nagpur rural consumers give the most importance to security issues like privacy to generate trust. The privacy of consumers' can be improved by ensuring their trust and their feedback about their online shopping.

2. There is a need to create greater awareness and encourage internet marketing in rural areas of Nagpur so online marketers should create more awareness about internet marketing to sell their products online and should use different online channels.

3. Online stores should use and effective implementation of website factors such as information design, features, communication, privacy, and security, as a marketing tool by which trust towards the website can be created among the rural consumers and consistently enhance purchase intention.

\section{Scope of the Research}

In the study, the study and survey will be conducted each and every one the way through a structured questionnaire to collect the statistics and facts from the targeted respondents of the Nagpur district State of Maharashtra to measure the factors affecting of internet marketing on consumers and their behavior, and applicability of eMarketing approaches among the consumers and online businesses so the scope of it would help to rural consumer behavior study and for e-marketer.

Different online shopping sites effect will be selected from the selected rural places within the Nagpur Region to conduct research study.

The research emphasizes on internet marketing impact of rural consumers in Nagpur district and their buying behavior.

\section{Bibliography}

1. V. Kumar and Denish Shah, (2004) "Pushing and Pulling on the Internet", Marketing research, spring.).

2. J Suresh Reddy, (May 2003) "Impact of E-commerce on marketing”, Indian Journal of Marketing., vol xxxiii, No.5.

3. Ruch Nayyar (2010), to study the website factors on consumers online buying behavior in India, vol 1Issue 1

4. Miyazaki, A. (2001). Consumer Perception of Privacy and Security Risks for Online Shopping. The Journal of Consumer Affairs, 35(1), 27-36.

5. https://en.wikipedia.org/wiki/Nagpur_district

6. Kotler, Philip, and Keller, Kevin (2011), "Marketing Management", 13th Edition, Prentice Hall of India Private Limited, New Delhi.

7. Schiffman, L. G., And Kanuk (2007), “Consumer Behavior", Prentice-Hall International, New Jersey, pp.3.

8. Armstrong, G. \& Kotler, P. (2005), “Marketing: an introduction”, USA: Pearson, New Jersey, 7th Edition.

9. Constantinides, E. (2004), Influencing online consumer behavior: the web experience, Internet Research 111-126.

10. Khan, Martin; Consumer Behavior, New Age Internationa! Publisher, 2001 edition, page 2. 